\title{
Primary Teachers' Insights on the Use of the Internet in their English as a Foreign Language Lessons: A Research Case Study
}

\author{
Dolores Ramírez Verdugo \\ Isabel Alonso Belmonte \\ Departamento de Didácticas Específicas \\ Facultad de Formación de Profesorado y Educación \\ Universidad Autónoma de Madrid
}

Received: 29-11-06 / Accepted version: 12-03-07

ISSN: $1697-7467$
'Technology is an area of the curriculum, as well as a tool for learning, in which teachers must demonstrate their own capacity for learning' (Bredekamp \& Rosegrant 1994: 61)

\begin{abstract}
While language teachers are progressively aware of the potential benefits of technology in foreign language instruction, one challenge they face is how to implement effective technology-based language tasks. This paper reports on the results from a case study on the instructional experience of a group of teachers in a research project aimed at investigating the effects of Internet-based instruction on six year old children's linguistic outcome in English as a foreign language. The analysis of pre- and post- questionnaires provides data on the teachers' expectations, achievements and the difficulties they came across when using Internet-based tasks in the EFL classroom.
\end{abstract}

Keywords: teachers' instructional experience, young learners, English as a Foreign Language (EFL), internet-based technology and instruction.

RESUMEN: A la vez que el profesorado de idiomas se va concienciando de las potenciales ventajas de la tecnología en la enseñanza de lenguas extranjeras, se enfrenta al desafío de llevar a clase tareas eficaces basadas en el uso de la tecnología. Este artículo presenta los resultados de un estudio de caso sobre la experiencia de un grupo de profesores en un proyecto de investigación sobre los efectos de la enseñanza a través de Internet en la producción lingüística en inglés de niños de seis años. El análisis de los cuestionarios pre y post test proporciona datos sobre las expectativas de los profesores, sobre sus logros y las dificultades a las que se enfrentaron al llevar a clase de inglés tareas basadas en el uso de Internet.

Palabras clave: experiencia docente de maestros, enseñanza a niños, Inglés como Lengua Extranjera (EFL), enseñanza de idiomas a través de internet. 


\section{INTRODUCTION}

Interest in using computer-based technology as an instructional medium with children is growing around the world. Many educators, parents and national governments are convinced that early interaction with computer-based technology stimulates learning and gives children a head start on success in the technological world of the future. Since the initial introduction of computers into the field of second/foreign language education, a large number of practitioners have concurred that this technology holds great potential for language learning. Cubillos (1998), Salaberry (2001) or Liu et al. (2002) offer thorough reviews of previous literature. However, data shows that computer-based technologies' potential to enhance children's learning outcome has not revealed in all its power in the primary classroom, being largely under utilized (Cuban, 2001).This reality is most evident in the foreign language classroom. A survey carried out among 930 British primary schools in 2003 points out that $95 \%$ of foreign language teachers in primary education made little or no use of the Information and Communication Technologies (henceforth ICTs) in their lessons (DfES, 2000-2003). This evidence is also confirmed in Spain by the National Agency of Education Quality and Accreditation report on the situation of EFL primary teachers working in Spanish state schools (Maldonado 2004). Literature on ICTs and education points at several reasons for this: certain resistance to technology from some instructors and organizations (Turbill 2001), the lack of trained language teachers in ICTs at the elementary school level, the lack of quality software titles (Haugland \& Shade 1994), the lack of adequate planning, budgetary constraints, the introduction of ICTs in Primary schools in response to pressure from outside groups (parents, software developers, etc.), and not to response to needs analysis of children's social, intellectual and physical development (Cordes \& Miller 2000; Wartella et al. 2000; Angrist \& Lavy 2002; etc.).

Given the increasing demands for educators to include technology into the curriculum, many teachers might be attracted by the resources the Internet can bring into the classroom. However, there is insufficient objective data to assess how ICTs instruction is perceived by teachers, as the major facilitator agents of the learning process. Very few studies (Williams et al. 2000; Plowman et al. 2002; Beauchamp, 2004) have been conducted on teachers' insights into and experience with the real use of technology with young learners in the classroom. To fulfil this caveat, this investigation provides data on teachers' use of Internet technology and materials in Primary Education. More specifically, this paper analyses a set of questionnaires which report on a group of teachers' instructional experience with the Internet-based tasks in the EFL classroom. The analysis of these data reveals issues for other teachers, foreign language and ICT experts and pedagogy researchers. Besides, the findings obtained can be useful for educational authorities when investing in ICTs and in primary teacher's professional development in EFL.

\section{RESEARCh DESIGN}

This investigation was carried out within the framework of a wider research project about the effects of informed instruction combined with Internet-based technology (Learning English with the Internet at school: A longitudinal research study in Madrid. UAM financed research project no. 1007030002/36). The study reported on here was aimed at examining the 
influence that digital stories, songs and games may have in improving six year-old children's linguistic achievement in EFL. The project was carried out at six different schools of Primary Education in Madrid with similar levels of social and cultural characteristics (information available at: http://www.educa.madrid.org) during the second semester of the academic year 2005.

A total number of 220 children participated in the project and the main facilitators at schools were six Spanish EFL teachers. They all had previous experience in several national and international research and European Comenius teaching projects in recent years. The type of instruction they offer is based on learner-centred pedagogies in foreign language teaching.

In each school, two groups of students were selected: a control group and an experimental one. Both groups had the same EFL teacher, so, it was the teacher who decided which group would be the experimental and control one. The average number of students per class was 20. A total number of 220 children participated in the project. The control group received English language lessons based on teacher instruction and the exploitation of an EFL text book specifically targeted at Spanish learners (Zoom 1, by Richmond Publishing-Santillana, 2003) during two sessions per week. This textbook's main goal is to develop oral communicative competence through listening and oral activities such as songs, games and short stories based exclusively on visual input. The basic contents of the textbook are organized into three main areas: topics, notions/concepts and functions. This syllabus is illustrated in Table 1.

Table 1: Summary of Zoom 1's table of contents (pp. 2-3).

\begin{tabular}{|c|c|c|c|}
\hline Unit & aim & vocabulary & language \\
\hline Hello & $\begin{array}{l}\text { Classroom } \\
\text { instructions }\end{array}$ & $\begin{array}{l}\text { People: girl, boy, teacher. } \\
\text { Actions: stand up, sit down, listen, } \\
\text { look and stop. }\end{array}$ & $\begin{array}{l}\text { Hello! } \\
\text { I'm... }\end{array}$ \\
\hline My class & Naming objects & $\begin{array}{l}\text { Numbers: one, two } \\
\text { Objects: pencil, book, table, chair. } \\
\text { Colors: red, blue. }\end{array}$ & $\begin{array}{l}\text { A pencil, please. } \\
\text { Thank you. } \\
\text { Look! A book! }\end{array}$ \\
\hline$M e$ & Describing objects & $\begin{array}{l}\text { Face: eyes, ears, mouth and nose. } \\
\text { Numbers: three and four. } \\
\text { Shapes: triangle and star. }\end{array}$ & $\begin{array}{c}\text { It's green! } \\
\text { It's a nose! } \\
\text { Look! Three stars! }\end{array}$ \\
\hline You and me & \multicolumn{2}{|r|}{ Revision } & Poem: You and me! \\
\hline My family & Expressing feelings & $\begin{array}{l}\text { Family: mother, father, sister. } \\
\text { Emotions: Happy and sad. } \\
\text { Colors: White, black. } \\
\text { Numbers: five and six. }\end{array}$ & $\begin{array}{c}\text { What's your name? } \\
\text { How are you? } \\
\text { Look! Five red } \\
\text { stars! }\end{array}$ \\
\hline My pets & Talking about pets & $\begin{array}{l}\text { Pets: fish, cat, bird and dog. } \\
\text { Numbers: seven and eight. } \\
\text { Actions: fly, swim, run. }\end{array}$ & $\begin{array}{l}\text { It's a brown dog. } \\
\text { It's big. } \\
\text { A dog can run. }\end{array}$ \\
\hline My house & \multicolumn{2}{|r|}{ Revision } & Poem: My family! \\
\hline $\begin{array}{l}\text { Day and } \\
\text { Night }\end{array}$ & Describing actions & $\begin{array}{l}\text { Nature: day, night, sun and moon. } \\
\text { Action: sleep and play. } \\
\text { Emotions: Tired } \\
\text { Numbers: nine and ten. }\end{array}$ & $\begin{array}{l}\text { Your turn! } \\
\text { Let's play! } \\
\text { Two birds! }\end{array}$ \\
\hline A picnic & $\begin{array}{l}\text { Talking about } \\
\text { preferences }\end{array}$ & $\begin{array}{l}\text { Food: Apples, hamburgers, salad. } \\
\text { Drinks: milk and lemonade. } \\
\text { Clothes: shorts, skirt and hat. }\end{array}$ & $\begin{array}{l}\text { I like apples. } \\
\text { A hamburger, } \\
\text { please. } \\
\text { A blue hat. }\end{array}$ \\
\hline Let's play & & Revision & $\begin{array}{c}\text { Poem: I'm seven } \\
\text { today! }\end{array}$ \\
\hline
\end{tabular}


The main listening activities found in the textbook include the following tasks: listen, point and say, look, listen and act, listen and circle, listen and colour, listen and draw. These tasks were mainly presented to the class as a whole group where students individually and, again, as a whole group respond to the oral input received. No use of Internet-based technology was contemplated for this group.

The experimental group also received EFL lessons during two sessions weekly. However, while during one session young learners received the same kind of instruction as the control group, based on teacher instruction and the exploitation of the text book, the other session was devoted to working on a selected number of digital materials selected from Kindersite (www.kindersite.org), an international project based Internet site which offers hundreds of direct links to graded content in the form of games, songs and stories. In order to facilitate the integration of these Internet-based materials in the daily teaching practice, the research leaders designed and provided an Internet-based syllabus. This syllabus was meant to support and develop the common objectives, contents and skills worked on at this age in any primary school in Spain, according with the present Spanish Law of Education. Kindersite digital materials were selected according to their degree of difficulty (adequate for 6 year old children) and were classified according to two main parameters: topics or major themes arranged in semantic groups, and notions and concepts such as actions, abilities, etc. For this classification we took into account and adapted to our context the guiding principles used in the Cambridge Young Learners English Tests (2003). Besides, each digital activity was characterized according to the language functions presented (i.e. narrating, following instructions, requesting, etc.), the main grammatical, lexical or phonetic points worked on, the language skills (i.e. listening) demanded and also the required interface abilities (i.e. listen, watch and react by clicking on arrows; click on the arrows to follow the story; click on parts of picture, watch and listen, etc.).

To illustrate the type of digital activities which integrate the above mentioned Internet based syllabus, Table 2 presents the analysis and classification of a story ("The Wishing Tree") in terms of the topics and notions covered, the language functions presented, the main grammatical and lexical elements worked on, and also the required interface abilities.

Table 2: Analysis and classification of the digital story "The Wishing Tree".

The Wishing Tree (from BBC)

http://www.bbc.co.uk/schools/laac/story/wish/sound.shtml

\begin{tabular}{|l|l|l|l|l|l|}
\hline Topics & Notions/Concepts & Functions & Grammar & $\begin{array}{l}\text { Language } \\
\text { Skills }\end{array}$ & $\begin{array}{l}\text { Required } \\
\text { Interface } \\
\text { Abilities }\end{array}$ \\
\hline $\begin{array}{l}\text { Seasons: } \\
\text { Summer; Forest } \\
\text { Animals; Home; }\end{array}$ & $\begin{array}{l}\text { Actions: tiding, } \\
\text { dancing, playing music; }\end{array}$ & $\begin{array}{l}\text { Following } \\
\text { instructions; } \\
\text { narrating }\end{array}$ & $\begin{array}{l}\text { Present \& } \\
\text { past tenses }\end{array}$ & Listening & $\begin{array}{l}\text { Listen, watch and } \\
\text { react by clicking } \\
\text { on objects }\end{array}$ \\
\hline
\end{tabular}


The selected stories followed a simple narrative line the young learners needed to understand to continue with the story. The multi-sensory character of these digital materials helped to create an immediate context for the lexis and actions presented in the narration. Children were requested to perform two different types of tasks. First, they were asked to follow the narrator's instructions, reacting to commands such as Roll the mouse on the screen .../ Click on the screen, object or character to ... And then, they were requested to respond to simple questions by selecting the right object after listening to simple questions such as Can you find + an object?/Is it really + object? / What do you think it is? The oral input was reinforced by the visual cues that were highlighted as the child rolled the mouse over the screen, which could facilitate scaffolding learning.

To facilitate a better integration of the syllabus into the EFL curriculum, some pre- and post computer work was agreed on and designed by both researchers and teachers. Precomputer activities presented to the whole group were intended to activate prior knowledge about the topics and notions covered in the story. The aim of post-computer work was to reinforce language acquisition through pair work and peer-collaboration.

\section{THE PRESENT STUDY}

\subsection{Objectives}

Within this research framework, the present investigation aims at gathering data on EFL teachers' use of Internet technology and materials in Primary Education. Our main goal is to answer these research questions:

1. What are the teachers' expectations and preconceptions about the use of the Internet for foreign language learning purposes?

2. What are the achievements they accomplish when using Internet in their lessons?

3. What are the real difficulties they come across when using Internet in their lessons?

\subsection{Data Collection}

For the purpose of this analysis, several research instruments were created. A pre and post questionnaire design was used to collect quantitative and qualitative information about foreign language teachers' preconceptions, expectations, achievement and the difficulties they came across when using computer mediated instruction. Post questionnaires also gathered data on teachers' pedagogical practices concerning tasks and materials, classroom management, and finally, on their assessment on children's performance and language learning. In addition, as further research instruments, teachers' diaries were also devised, together with classroom observation in all groups. The researchers, as external observers, used these instruments to validate and complete the findings provided by the questionnaires on the daily Internet-based tasks and activities carried out in the classroom, the teachers' methodology and classroom management. In the present paper we specifically report on the results of the pre and post questionnaires.

As mentioned above, two questionnaires were devised. A pre-questionnaire was designed to gather initial data on teachers' previous knowledge and conceptions about the benefits of 
using ICTs in the EFL Primary classroom. A post-questionnaire was also designed to trace the implementation of the project in the six state schools and to learn whether teachers' preconceptions about the use of ICTs had changed or not.

Both pre- and post-questionnaires included open questions, alternative yes/no questions and closed questions. A 5-point scale was used to quantify the closed questions: (1) represents the most negative assessment (No value, it does not help; it does not facilitate learning) and (5) represents the most positive evaluation (High value; it helps a lot; it highly facilitates learning) (See Appendices I and II). Analyses of the most frequent tendency of each of the items were performed. To quantify the data assessed in a 5-point scale, percentages were calculated and are reported to support the discussion.

The pre-questionnaire (42 items) was divided into 7 main sections. The first section requested information about the available Internet facilities at school (i.e. whether computers are located in the classroom or in the computer lab, etc.). The second section was intended to gather evidence about the teachers' previous experience in the use of the Internet as a tool in the FL classroom. Questions about the frequency of use, the kind of materials downloaded, the quality of those materials and difficulties in their use, and the teachers' previous beliefs about the usefulness of ICTs were posed. Finally, the remaining sections asked for information about their preconceptions on the effect that ICT based instruction may have in:

1. Improving language learning and the possible difficulties a computer-mediated class may bring.

2. Adapting teaching objectives to the students' different abilities and interests.

3. Facilitating feedback, assessment, time management.

4. Determining young learners' significant learning and motivation.

5. Promoting learners' participation and autonomy on learning to learn.

6. Bettering the classroom atmosphere.

The post-questionnaire (50 items) requested information on the same areas than the prequestionnaire to check whether the teachers' initial conceptions about the use of ICTs had changed after the application of the program. Furthermore, the instructors were asked to assess the effectiveness and limitations of the use of the Internet. Finally, they were asked to mention positive and negative issues about the implementation of the program and to provide a global assessment.

\section{RESULTS}

In this section, we present and discuss the results obtained from the analysis of the teachers' questionnaires. Generally, the study of the pre-questionnaires indicate that the teachers participating in this project had very positive beliefs about the usefulness of Internet-based materials as a tool to improve the process of learning in general, and foreign languages, in particular. As regards the outcome of the post-questionnaires, these teachers realize that working with computers entails new challenges on pedagogical practices and classroom management. The effects of ICT instruction on language learning, as they perceive it, are positive. They reported gains in children's oral understanding and vocabulary learning. Therefore, 
data reveal that after the implementation of the program our teachers show an informed idea about the advantages and shortcomings of ICT mediated instruction. The analysis of teacher's diaries and the results of researchers' observations confirmed the data obtained from the preand post questionnaires.

For presentation purposes, the data is displayed under corresponding headlines and subsections:

- Teachers' experience with the Internet, before, during and after the project.

- Teachers' beliefs and opinions about the usefulness of Internet-based materials as a tool to teach foreign languages, before, during and after the project.

- Teachers' conceptions about the effects that Internet-based materials may exert on the teaching/learning process, before, during and after the project.

- Finally, a summary of the main results is presented in section 4.5. and Table 3.

\subsection{Teachers' experience with the Internet, before, during and after the project}

Before the project, all teachers claimed they had experience using the Internet to search for resources to complement their teaching. In the pre-questionnaires, teachers said the most common Internet-based materials found were: stories, songs, games, cultural activities, flashcards, handcraft activities, and exercises of any kind. Among all of them, songs (70\%) and stories (66.7\%) were considered the most useful and valuable materials, followed by games $(61.7 \%)$. All these Internet-based materials were contemplated as very motivating and they were highly recommended to be used at home. Yet, 3 teachers felt that the level of difficulty of some of those materials was very high for young learners.

In the post-questionnaires, the rank awarded to these digital materials slightly decreased and this time stories (63.3\%) were just slightly better ranked than songs (61.7\%) and games $(61.7 \%)$. Finally, the access to Internet facilities was regarded as relatively fast though problems getting access to the site were also reported in some sessions.

\subsection{Teachers' beliefs and opinions about the usefulness of Internet-based materials as a tool to teach foreign languages, before, during and after the project}

Before and after the project, all teachers showed consensus on two facts: 1) Internetbased materials can be fully integrated in the teaching practice in Primary; and 2) Internetbased materials could improve foreign language learning. As regards this second item, before the project foreign language educators believed that Internet could make improvements on: vocabulary acquisition (70\%), reading comprehension (66.7\%), listening comprehension $(63.3 \%)$ and grammar competence $(63.3 \%)$. Other areas, however, were viewed as less likely to improve by the use of those materials: intonation and pronunciation (55\%), oral fluency $(50 \%)$ and writing $(41.7 \%)$. After the implementation of the program, our teachers still believed that vocabulary was the first item that had improved $(61.7 \%)$, followed by listening comprehension $(61.7 \%)$, intonation and pronunciation $(61.7 \%)$, and reading comprehension $(61.7 \%)$. Finally, grammar competence $(41.6 \%)$ was only poorly assessed after the program, while teachers' initial expectations on oral fluency $(50 \%)$ and writing $(38.3 \%)$ were confirmed. 
As the data reflect, apart from the development in vocabulary learning and listening comprehension, teachers reported gains in the pronunciation and intonation of formulaic speech and phrases and words which appeared in the stories, games and songs. In addition, even though young learners were not expected to read at this stage, they, as their teachers stated, had started to perceive the differences between the sound and spelling of some of the lexis in the materials. In fact, most of these materials include both oral input and written text. Thus, learners were beginning to read individual words associating graphics to phonics. On the other hand, the fact that grammar is implicit to the narrative structure of stories, for instance, may have led teachers not to consider any explicit improvement in this area. Other areas such as oral fluency and writing were beyond the developmental linguistic stage of these learners and, hence, the focus of this project.

In the pre-questionnaires, when the teachers were asked which difficulties may arise in the EFL classroom when using Internet-based materials, most educators basically foresaw the following problems in this order:

1. The lack of time exposure to the Internet-based activities.

2. The difficulty of some of these materials for young learners.

3. The quality of some of these materials for young learners.

The rating in comparison with the post-questionnaires hardly changes with regard to the lack of time exposure and the difficulty of some of the materials for young learners. However, in the post-questionnaires, the quality of the materials was not regarded as a difficulty for both teachers and young learners.

Finally, in the pre-questionnaires teachers claimed that Internet-based materials should be used weekly (50\%) during periods of 40-45 minutes. However, after the project, they considered that it would be better to have shorter but more frequent sessions per week (i.e. periods of 30-35 minutes two or three times a week).

\subsection{Teachers' conceptions about the effects that Internet-based materials may exert on the teaching/learning process, before, during and after the project}

Before and after the project, most teachers believed that Internet use could improve the teaching/learning process. As regards mixed ability teaching, most educators claimed that Internet-based materials could fundamentally help to improve immediate feedback $(66.7 \%)$ and to guarantee the participation of all students (61.7\%). After the implementation of the program, the same opinion was held regarding the immediate feedback (66.7\%), while the item concerning the participation of all the students was slightly increased (66.7\%). Some other items such as to adapt the timing of the activity to each of the students' capabilities (53.3 vs. $61.7 \%$ ); to help teachers to support individual students' interests (55 vs. $58.3 \%$ ) and finally, to help teachers to support individual students' different abilities and needs (55\%) were only relatively well considered both in the pre-questionnaires and the post-questionnaires. The only item which decreased (from 58.3\% to 50\%) was the one related to better time management.

As far as significant learning is concerned, most teachers claimed before and after the project that Internet-based materials could principally help young learners learn by playing 
with amusing methodology (71.6\%), to promote learners to assume an active role in their own learning (71.6\% vs. $66.7 \%$ ), young learners to increase their motivation (70\% vs. $78.3 \%$ ). Other items were also well considered before and after the implementation of the program, such as help learners to fix and remember better what they have learnt (70\% vs. $61.7 \%$ ), to plan different activities to work on the same objectives (63.3\% vs. 61.7\%) and to connect new contents to their prior knowledge $(61.7 \%)$.. Therefore, the experience during the project confirmed teachers' expectations on the positive effects of the use of internet-based materials with young learners.

Regarding learners' autonomy, items such as 'to revise their performance during the activity' (63.3\% vs. $50 \%)$ or 'to self assess their own process of learning' (61.6\% vs. $45 \%)$, were only moderately ranked. Hence these teachers believed that ICTs, considering six-yearold children's developmental features, do not promote learners' autonomy very much at this age. The teacher would still need to monitor the learning process and the access, mainly at the very beginning, to technology.

Finally, as regards the EFL classroom environment, the participating teachers claim in the pre-questionnaires that Internet-based materials could help students to increase the feeling of wellbeing in the classroom (58.3\%), to promote peer collaboration $(53.3 \%)$ and communication in the classroom (53.3\%) and to control their behaviour (53.3\%). However, after the project, our teachers changed the ranking and expressed that Internet-based materials basically promoted peer collaboration (66.7\%) and the atmosphere in the classroom for students $(61.7 \%)$. Yet, they consider that the use of internet only partially help learners to promote communication in the classroom (55\%) and to control their behaviour (55\%).

\subsection{Summary}

In sum, the project was regarded very positively by the participating teachers. Among the positive aspects, they mentioned the importance of having access to real language, interesting stories and amusing activities. They believed that the use of technology was very motivating for learners and could promote collaboration among them. They estimated that students had improved their global understanding of oral messages with the use of Internet materials. Finally, they mentioned that this improvement in listening comprehension had also benefited their pronunciation. Some negative issues were also raised. In general, the level of the language in some of the materials was high and difficult for these young EFL learners. Some games were considered excessively simple and did not provide much language. Besides, the pace in some of the stories and songs was too fast for these children. On the other hand, some interface difficulties and classroom management were also mentioned: "It has taken a while until they have been able to use the web autonomously", "in some stories there is no possibility of rereading the previous page" or "it is difficult to deal with 20 children working with the computer at the same time".

Finally, the teachers highly valued the possibility of further exploiting the use the materials "in class and not only with the computer". In brief, all teachers found the experience valuable and useful. The following statement by one of the teachers may well summarize this global assessment: "I have found the Project very positive. The beginning was hard but the children have enjoyed and, I hope, learnt". Table 3 includes a summary of the instructors' assessment and ranking of the items under research before and after the project. 
Table 3: Summary of teachers' assessment and ranking of the research items.

\begin{tabular}{|c|c|c|}
\hline \multirow{3}{*}{$\begin{array}{l}\text { Most useful and } \\
\text { valuable } \\
\text { Internet-based } \\
\text { materials are: }\end{array}$} & 1. songs & 1. stories \\
\hline & 2. stories & 2. songs \\
\hline & 3. games & 3. games \\
\hline \multirow{7}{*}{$\begin{array}{l}\text { Internet can make } \\
\text { improvements on: }\end{array}$} & 1. vocabulary acquisition & 1. vocabulary acquisition \\
\hline & 2. reading comprehension & 2. listening comprehension \\
\hline & 3. listening comprehension & 3. intonation and pronunciation \\
\hline & 4. grammar competence & 4. reading comprehension \\
\hline & 5. intonation and pronunciation & 5. oral fluency \\
\hline & 6. oral fluency & 6. grammar competence \\
\hline & 7. writing & 7. writing \\
\hline $\begin{array}{l}\text { Internet-based } \\
\text { materials should be } \\
\text { used: }\end{array}$ & Weekly during periods of $40-45$ minutes. & $\begin{array}{l}\text { Two or three times a week during } \\
\text { periods of 20-25 / } 30-35 \text { minutes. }\end{array}$ \\
\hline \multirow{5}{*}{$\begin{array}{l}\text { Mixed ability teaching } \\
\text { and ICT effects on the } \\
\text { teaching/learning } \\
\text { process. Internet-based } \\
\text { materials could } \\
\text { fundamentally help }\end{array}$} & 1. to improve immediate feedback. & $\begin{array}{l}\text { 1. to guarantee the participation of all } \\
\text { students. }\end{array}$ \\
\hline & $\begin{array}{l}\text { 2. to guarantee the participation of all } \\
\text { students. }\end{array}$ & 2. to improve immediate feedback. \\
\hline & 3. to better time management. & $\begin{array}{l}\text { 3. the timing of the activity to each of } \\
\text { the students' capabilities. }\end{array}$ \\
\hline & $\begin{array}{l}\text { 4. to help teachers to support individual } \\
\text { students' interests and needs. }\end{array}$ & $\begin{array}{l}\text { 4. to help teachers to support individual } \\
\text { students' interests and needs. }\end{array}$ \\
\hline & $\begin{array}{l}\text { 5. the timing of the activity to each of the } \\
\text { students' capabilities. }\end{array}$ & 5. to better time management. \\
\hline \multirow{7}{*}{$\begin{array}{l}\text { Improving significant } \\
\text { learning. Internet- } \\
\text { based materials could } \\
\text { fundamentally help }\end{array}$} & $\begin{array}{l}\text { 1. learn by playing with amusing } \\
\text { methodology. }\end{array}$ & $\begin{array}{l}\text { 1. young learners to increase their } \\
\text { motivation. }\end{array}$ \\
\hline & $\begin{array}{l}\text { 2. to promote learners to assume an active } \\
\text { role in their own learning. }\end{array}$ & $\begin{array}{l}\text { 2. learn by playing with amusing } \\
\text { methodology. }\end{array}$ \\
\hline & $\begin{array}{l}\text { 3. young learners to increase their } \\
\text { motivation. }\end{array}$ & $\begin{array}{l}\text { 5. to promote learners to assume an } \\
\text { active role in their own learning. }\end{array}$ \\
\hline & $\begin{array}{l}\text { 4. learners to fix and remember better } \\
\text { what they have learnt }\end{array}$ & $\begin{array}{l}\text { 4. learners to fix and remember better } \\
\text { what they have learnt }\end{array}$ \\
\hline & $\begin{array}{l}\text { 5. to plan different activities to work on the } \\
\text { same objectives }\end{array}$ & $\begin{array}{l}\text { 5. to plan different activities to work on } \\
\text { the same objectives }\end{array}$ \\
\hline & $\begin{array}{l}\text { 6. to connect new contents to their prior } \\
\text { knowledge }\end{array}$ & $\begin{array}{l}\text { 6. to connect new contents to their prior } \\
\text { knowledge }\end{array}$ \\
\hline & $\begin{array}{l}\text { 7. to generalise new contents and apply } \\
\text { them to other contexts. }\end{array}$ & $\begin{array}{l}\text { 7. to generalise new contents and apply } \\
\text { them to other contexts. }\end{array}$ \\
\hline \multirow{2}{*}{$\begin{array}{l}\text { Improving learners' } \\
\text { autonomy. Internet- } \\
\text { based materials help } \\
\text { students to }\end{array}$} & 1. self assess their own process of learning. & $\begin{array}{l}\text { 1. revise their performance during the } \\
\text { activity. }\end{array}$ \\
\hline & $\begin{array}{l}\text { 2. revise their performance during the } \\
\text { activity. }\end{array}$ & $\begin{array}{l}\text { 2. self assess their own process of } \\
\text { learning. }\end{array}$ \\
\hline \multirow{4}{*}{$\begin{array}{l}\text { Improving EFL } \\
\text { classroom } \\
\text { environment. Internet- } \\
\text { based materials help } \\
\text { students to }\end{array}$} & $\begin{array}{l}\text { 1. increase the feeling of wellbeing in the } \\
\text { classroom. }\end{array}$ & 1. promote peer collaboration. \\
\hline & 2. promote peer collaboration. & $\begin{array}{l}\text { 2. increase the feeling of wellbeing in } \\
\text { the classroom. }\end{array}$ \\
\hline & 3. promote communication. & 3. promote communication. \\
\hline & 4. control their behaviour. & 4. control their behaviour. \\
\hline
\end{tabular}




\section{Discussion}

The analysis of the questionnaires indicates that the participating teachers believe in the capabilities and communicative potential of language technologies for second language teaching. We acknowledge that the number of questionnaires gathered is limited and hence can only reveal trends and not generalization. However, to our knowledge, there are not many studies on teachers' experiences with the use of Internet and six-year old young learners in an EFL setting. Besides, the outcome obtained, we believe, provides interesting hints to comment on within the context of young learners teaching practice and recent literature on enhanced technology learning.

\subsection{Usefulness of Internet-based materials as a tool to teach foreign languages}

The experience has been regarded as motivating for both teachers and learners, as previous studies on the use of technology in language learning have already reported (Kern 1995; Meunier 1997; Svensson 2003). All teachers showed consensus on two facts: Internet-based materials could be fully integrated in the foreign language classroom; and Internet-based materials could improve L2 learning. As regards the linguistic input, these teachers think the main linguistic areas where a gain can be obtained are vocabulary and listening. The interactive and multi-sensory (integrating sound, animation of pictures and printed text) character of the digital materials is highly regarded since they provide an immediate context which facilitates vocabulary learning and language understanding. Gains in listening skills seem to bring benefits to improve also children's coding and decoding of graphs and phonics facilitating the beginning of reading.

As regards methodology, the outcome of study indicates the usefulness of using precomputer activities to activate prior knowledge schema and, in turn, to better integrate the selected digital materials into the teaching practice. Another suggestion, based on the practice conducted, to facilitate integration of the digital material into the lesson refers to postcomputer work. Our teachers stressed the need of printing web page print-outs from the digital stories or games, for instance, to use them as the basis for follow-up classroom activities (retell the story, short role-plays, etc.). This reflects the importance of providing learners with some record of their Internet-based activities. This kind of practice links better the Internet activities to the rest of the curriculum.

Finally, as regards the foreign language classroom environment, the participating teachers considered that Internet-based materials promoted peer collaboration and bettered the atmosphere in the classroom for students.

\subsection{Limitations and future trends in the use of technology and Internet-based materials as a tool to teach foreign languages}

In spite of the mentioned capabilities and benefits, some limitations of technology and Internet-based materials were also identified. These instructors feel that the story-telling pace, for instance, is in some cases too fast even for native speakers. This, obviously, entails further difficulty for non-native learners. This restriction was carefully considered when selecting digital stories for this project. Thus, objective criteria such as the simplicity of grammar, 
vocabulary and narrative structure were taken into account to make the story predictable and facilitate comprehension. However, these issues point towards the need of improving specific materials. Suitable interface displays for children are needed, both from a cognitive and an ergonomic perspective, ensuring, at the same time, a safe and secure Internet environment for children. There is also a need of furthering in the design of adequate tasks for non-native speakers, adapting existent pedagogical practices and developing new ones.

As regards learners' autonomy, data gathered demonstrates that at this age learners are not independent in their learning process. 'This issue stresses the role that the instructor continues to have in a technological scenario. The teacher becomes essential in scaffolding learning within the child's 'zone of proximal development' (Vygotsky 1978; Painter 2001), maintaining children's interests, helping them with language understanding and activity completion, directing their attention towards relevant information, helping them to identify correct and incorrect responses in a progressively autonomous way, reinforcing active learning. The importance of the teacher's role in a computer-mediated classroom is not, hence, diminished but emphasized.

Another limitation refers to the modifications that the integration of new technologies entails for classroom-management and pedagogical practices. In the study reported on here, the access to the Internet was not available in the language classroom in most of the schools. This, undoubtedly, affected the development of the lesson. Students had to leave their usual learning environment, move to a new room, get the computers started, etc. The physical displacement of the necessary facilities affected, in turn, the control of children's behaviour and, finally, the lesson timing and procedure, as the analysis of the post-questionnaires reveal. In this respect, earlier studies also show that when computers are located in the classroom, children's developmental gains from using appropriate software are significantly greater than when they are in a computer classroom (Bredekamp \& Rosegrant, 1994; Shade 1996; Davis \& Shade 1999; Haugland 2000). The analysis of the teachers' questionnaires reveal that in order to integrate the digital materials into their teaching practice, learners need to have access to the computer in their classroom. These teachers also prefer to use these digital materials more frequently (perhaps two or three times a week) but for a shorter time (about 20 to 30 minutes rather than 40 minutes). This would facilitate the integration of technology in different stages of their lesson plan.

\subsection{Summary}

The intrinsic demands of this technology-based learning scenario may lead to a range of polarized reactions on the part of the instructors from blind enthusiasm to anxiety, confusion and finally rejection. As the results of the present study show, the teachers progressively moved from enthusiasm to a more informed knowledge on the effectiveness of an Internetbased syllabus and its limitations. Yet, they still feel positively about the use of ICTs in the classroom. Now they are aware of the need to improve and further adapt existent digital materials to integrate them appropriately in the foreign language curriculum. 


\section{Conclusion}

Technology can help teachers to improve access to the different types of existent media to support and extend traditional materials. Well-designed software can enrich language content and classroom tasks and also integrate curriculum across subject-matter areas such as literacy, science or mathematics (Clements 1999), etc. However, the use of technology in the educational context, as Pusack and Otto (1997) argue, implies the change of the roles the learner, the teacher and of the textbook, as well as modifications in methodology.

While textbooks offer selected texts and topics as a basis for language-learning activities, the Internet can provide a wide source of authentic target-culture materials. The challenge for the teacher is to integrate well-defined tasks, which response to language learning goals, in his/her daily teaching practice which enable learners to learn a foreign language. Tasks should help students adopt an active role during the learning process. Activities which include the connection between prior knowledge and new content; language review; internal language assessment to proceed with the task rather than only simplistic external appraisal (Well done! or Try again!) would reflect basic theoretical and practical principles of language learning through technology. Pedagogical practices which facilitate input perception and language learning are also necessary. In this respect, as suggested above, the inclusion of pre and post computer work, for instance, seems to be essential to focus on upcoming lexical items and language structures and reinforces intake (cf. Dudeney, G. 2000; Windeatt et al. 2000; Lewis 2004; Ramírez Verdugo \& Alonso, 2006).

There is, therefore, a need for pre- and in-service teacher training in order to integrate the technology into the curriculum and developing the critical skills to use technology effectively and assess the results. It is important for educators to understand how technology can best be used to improve the language learning experience. Multidisciplinary studies are required on earlier and different stages of language learning taking into account children's developmental, cognitive and linguistic characteristics with larger number of participating teachers and students. Educators, language pedagogy researchers, linguists and technologists need to work together in the design of technology-enhanced language tasks which facilitate significant learning. As Felix (2003: ix) argues, 'technological innovation is driven by many factors, but not one of them concerns a pedagogical imperative. There is no dialogue between teachers and technologists about what kind of technological innovation learners need: neither side knows how to begin the dialogue'. It is due time now, we claim, to begin and advance in such a dialogue, otherwise, the potentiality of technology-enhanced language learning will remain at a theoretical level without bringing any real benefit to foreign language learners.

\section{ACKNOWLEDGEMENTS}

We would like to thank UAM for their financial support during the development of this research project. We are also grateful to Dr. R. Marco for her help with the statistical analysis of the study and to Dr. A. González for her insights into the design of the questionnaires. We also thank Dr. A. McCabe (Saint Louis University, Madrid Campus) for her insightful comments on an earlier version of this manuscript. 


\section{REFERENCES}

Abbot, C., Lachs, V. \& Williams, L. (2001). "Fool's Gold or hidden treasure: are computers stifling creativity", in Journal of Education Policy, 16, 5: 479-487.

Angrist, J. \& Lavy, V. (2002). "New Evidence on classroom computers and pupil learning", in Economic Journal, 112, 482: 735-766.

Beauchamp, G. (2004). "Teacher Use of the Interactive Whiteboard in Primary Schools: towards an effective transition framework", in Technology, Pedagogy \& Education, 13, 3: 327-348.

Bredekamp, S., \& Rosegrant, T. (1994). "Learning and teaching with technology", in J.L. Wright \& D.D. Shade (eds.), Young Children: Active Learners in a Technological Age. Washington, DC: National Association for the Education of Young Children, 53-61.

Clements, D. H. (1999). Young children and technology. Dialogue on early childhood science, mathematics, and technology education. Washington, DC: American Association for the Advancement of Science, Project 2061. Available online at: http:// www.project2061.org/ newsinfo/earlychild/ experience/clements.htm.

Cordes, C., \& Miller, E. (2000). Fool's Gold: A Critical Look at Computers in Childhood. College Park, MD: Alliance for Childhood. Available online at: http:// www.allianceforchildhood.net /projects/ computers/ computers_reports_fools_gold_contents.htm.

Cuban, L. (2001). Oversold and Underused: Computers in the Classroom. Cambridge, MA: Harvard University Press.

Cubillos, J. (1998). "Technology: A step forward in the teaching of foreign languages", in J. Harper, M. Lively, \& M. Williams (eds), The Coming of Age of the Profession: Issues and Emerging Ideas for the Teaching of Foreign Languages. Boston: Heinle \& Heinle, 7-52.

Davis, B. C., \& Shade, D. D. (1999). "Integrating technology into the early childhood classroom: The case of literacy learning", in D. D. Shade (ed), Information Technology in Childhood Education Annual. Norfolk, VA: Association for the Advancement of Computing in Education, 221-254.

DfES (Department of Education and Employment) (2000-2003). Survey of Information and Communication Technology in Schools 2000-2003. UK: Crown Copyright.

Dudeney, G. (2000). The Internet and the Language Classroom: A Practical Guide for Teachers. New York: Cambridge University Press.

Felix, U. (Ed.) (2003). Language Learning Online: Towards Best Practice from the series Language Learning and Language Technology. Lisse: Swets \& Zeitlinger.

Haugland, S.W.(2000). "Early childhood classrooms in the 21st century: Using computers to maximize learning", in Young Children, 55, 1: 12-18.

Haugland, S.W. \& Shade, D.D. (1994). "Software Evaluation for Young Children", in J.L. Wright y D.D. Shade (eds.), Young Children: Active Learners in a Technological Age. Washington: NAEYC, 63-76.

Johnson, D. (1996). "Evaluating the impact of technology: The less simple answer", in The Education Technology Journal, 5. Available online at: http://emifyes.iserver.net/fromnow/jan96/reply.html

Kern, R. (1995). "Restructuring classroom interaction with networked computers: Effects on quantity and quality of language production", in Modern Language Journal, 79: 457-476.

Lewis, G. (2004). The internet and young learners. Oxford: OUP.

Liu, M., Moore, Z., Graham, L. \& Lee, S. (2002). "A look at the research on computer-based technology use in second language learning: A review of the literature from 1990-2000", in Journal of Research on Technology in Education, 34: 250-273. 
Maldonado, A. (2004) (Coord.). La adecuación de las titulaciones de Maestro en el Espacio Europeo de Educación Superior. ANECA Internal Report. Available online at: http:// www.ugr.es/ magister/proyecto_aneca/informe\%20final/Informe\%20final\%20Magisterio.pdf.

Meunier, L.E. (1997). "Personality and motivational factors in computer- mediated foreign language communication", in J. A. Muyskens (ed.), New Ways of Learning and Teaching: Focus on Technology and Foreign Language Education. Boston: Heinle \& Heinle, 145-197.

Painter, C. (2001). Learning through Language in Early Childhood. London: Continuum.

Plowman, L., Mateer, J. \& Leakey, A. (2002). Connecting schools, libraries and Community Education Centres with ICT: an evaluation of the CREATIS Project. Interchange research report for Scottish Executive Education Department. Available online at: http:// www.scotland.gov.uk/library5/education/creatis.pdf

Pusack, J. \& Otto, S. (1997). "Taking control of multimedia", in M. Bush \& R. Terry (eds.), Technology-Enhanced Language Learning. Lincolnwood: National Textbook Company, 146.

Ramírez Verdugo, M. D. \& Alonso, I. (2006). "Integrating Internet in the EFL Primary Classroom: a proposal of digital syllabus for Spanish young learners", in Children and Teenagers (CATS), the YLSIG Newsletter. Kent: IATEFL, 10-14.

Salaberry, M.R. (2001). "The use of technology for second language learning and teaching: A retrospective", in Modern Language Journal, 85, 1: 39-56.

Shade, D.D. (1996). "Are you ready to teach young children in the $21^{\text {st }}$ century?", in Early Childhood Education Journal, 24, 1: 43-44.

Svensson, P. (2003). "Virtual worlds as arenas for language learning", in F. Uschi (ed.), Language Learning Online: Towards Best Practice. Lisse: Swets \& Zeitlinger, 123-142.

Turbill, J. (2001). "A researcher goes to school: Using technology in the Kindergarten literacy curriculum", in Journal of Early Childhood Literacy, 1, 3: 255-279.

Vygotsky, L. S. (1978). Mind in Society: The Development of Higher Psychological Processes. Cambridge, MA: Harvard University Press.

Wartella, E., O'Keefe, B. \& Scantlin, R. (2000). Children and Interactive Media. A report for the Markle Foundation. Available online at: http// www.markle.org/programs/_programs_children_ utexas.stm.

Williams, D., Coles, L., Wilson, K., Richardson, A. \& Tuson, J. (2000). "Teachers and ICT: current use and future needs", in British Journal of Educational Technology, 31, 4: 307-320.

Windeatt, S., Hardisty, D. \& Eastment, D. (2000). The Internet. Oxford: OUP. 


\section{APPENDIX I}

PRE-QUESTIONNAIRE

School ICT facilities

\begin{tabular}{|l|l|l|}
\hline Questions & YES & NO \\
\hline 1. Does your school have ICT facilities? & & \\
\hline 2. Do you think you could use the Internet facilities of the school? & & \\
\hline 3. Is it possible for you to have access to the Internet in the foreign language classroom? & & \\
\hline
\end{tabular}

Teachers' previous experience with Internet

\begin{tabular}{|c|c|c|c|c|c|}
\hline \multirow[b]{2}{*}{ Questions } & \multicolumn{5}{|l|}{ Frequency } \\
\hline & Never & $\begin{array}{c}\text { Between } \\
1 \text { and } 6 \\
\text { times a } \\
\text { year }\end{array}$ & $\begin{array}{c}\text { Between } \\
7 \text { and } 12 \\
\text { times a } \\
\text { year }\end{array}$ & $\begin{array}{c}\text { Between } 2 \\
\text { and } 4 \\
\text { times a } \\
\text { month }\end{array}$ & $\begin{array}{c}\text { More } \\
\text { than } \\
\text { once a } \\
\text { week }\end{array}$ \\
\hline \multicolumn{6}{|l|}{ 4. ¿How often do you use the Internet? } \\
\hline \multicolumn{6}{|l|}{$\begin{array}{l}\text { 5. ¿Do you often search for digital resources and Internet web } \\
\text { sites to complement your teaching? }\end{array}$} \\
\hline \multicolumn{6}{|l|}{$\begin{array}{l}\text { 6. ¿Have you ever found any interesting Internet based } \\
\text { material which could be used in your EFL lessons? }\end{array}$} \\
\hline $\begin{array}{l}\text { 7. If affirmative, what kind of material it was and how often } \\
\text { did you search for them? }\end{array}$ & Never & $\begin{array}{c}\text { Between } \\
1 \text { and } 6 \\
\text { times a } \\
\text { year }\end{array}$ & $\begin{array}{c}\text { Between } \\
7 \text { and } 12 \\
\text { times a } \\
\text { year }\end{array}$ & $\begin{array}{c}\text { Between } 2 \\
\text { and } 4 \\
\text { times a } \\
\text { month }\end{array}$ & $\begin{array}{c}\text { More } \\
\text { than } \\
\text { once a } \\
\text { week }\end{array}$ \\
\hline \multicolumn{6}{|l|}{ 7.1. Tales } \\
\hline \multicolumn{6}{|l|}{ 7.2. Songs } \\
\hline \multicolumn{6}{|l|}{ 7.3. Games } \\
\hline \multicolumn{6}{|l|}{ 7.4. Others (detail them): } \\
\hline $\begin{array}{l}\text { 8. Please, rank the usefulness and value of these Internet- } \\
\text { based materials: }\end{array}$ & Null & Minimum & Medium & $\begin{array}{l}\text { High } \\
\text { value }\end{array}$ & $\begin{array}{l}\text { Very } \\
\text { high } \\
\text { value } \\
\end{array}$ \\
\hline \multicolumn{6}{|l|}{ 8.1. Tales } \\
\hline \multicolumn{6}{|l|}{ 8.2. Songs } \\
\hline \multicolumn{6}{|l|}{ 8.3. Games } \\
\hline \multicolumn{6}{|l|}{ 8.4. Others (detail them): } \\
\hline \multicolumn{4}{|c|}{$\begin{array}{l}\text { 9. If case you answered positively to questions } 6 \text { and } 7 \text {, did you have any problem when using any of } \\
\text { the above mentioned Internet based activities in the classroom? }\end{array}$} & YES & NO \\
\hline \multicolumn{6}{|l|}{ 10. Do you have any suggestion to optimize its use? } \\
\hline \multicolumn{4}{|c|}{ 11. As a rule, would you recommend these Internet based materials to be used by children at home? } & YES & NO \\
\hline \multicolumn{6}{|l|}{ 12. Why? } \\
\hline
\end{tabular}

Teachers' beliefs and opinions about the usefulness of Internet based materials as a tool to teach foreign languages. Please, answer the following questions using the following 5 point scale:

1. It does not facilitate learning; 
2. It scarcely helps learning;

3. It quite helps learning;

4. It highly facilitates learning;

5. It helps learning very much.

\begin{tabular}{|c|c|c|c|c|c|}
\hline \multirow{2}{*}{$\begin{array}{l}\text { 13. Would you think it is possible to integrate } \\
\text { digital materials in your daily teaching practice? } \\
\text { 14. On which of the following items do you } \\
\text { believe Internet based materials could facilitate } \\
\text { learning in an EFL setting? }\end{array}$} & \multicolumn{2}{|l|}{ YES } & \multicolumn{3}{|c|}{$\mathrm{NO}$} \\
\hline & 1 & 3 & \multicolumn{2}{|c|}{4} & 5 \\
\hline \multicolumn{6}{|l|}{ 14.1. Vocabulary acquisition. } \\
\hline \multicolumn{6}{|l|}{ 14.2. Grammar competence. } \\
\hline \multicolumn{6}{|l|}{ 14.3. Oral fluency. } \\
\hline \multicolumn{6}{|l|}{ 14.4. Intonation and Pronunciation. } \\
\hline \multicolumn{6}{|l|}{ 14.5. Listening comprehension. } \\
\hline \multicolumn{6}{|l|}{ 14.6. Reading. } \\
\hline \multicolumn{6}{|l|}{ 14.7. Writing. } \\
\hline \multicolumn{2}{|c|}{$\begin{array}{l}\text { 15. What difficulties may arise in the L2 classroom when using } \\
\text { Internet-based materials? }\end{array}$} & \multicolumn{3}{|l|}{ YES } & NO \\
\hline \multicolumn{6}{|c|}{ 15.1. The difficulty of some of these materials for young learners. } \\
\hline \multicolumn{6}{|c|}{ 15.2. The difficulty of teaching some of these materials. } \\
\hline \multicolumn{6}{|l|}{ 15.3. These materials' lack of quality and teaching value. } \\
\hline \multicolumn{6}{|c|}{ 15.4. The lack of time exposure to these materials during the week. } \\
\hline \multicolumn{6}{|l|}{ 15.5. Others (detail them): } \\
\hline \multicolumn{2}{|c|}{$\begin{array}{l}\text { 16. How often would you use Internet based materials in your EFL } \\
\text { Primary lessons? }\end{array}$} & Never & Daily & Weekly & Every fortnight \\
\hline \multicolumn{2}{|c|}{$\begin{array}{l}\text { 17. For how long do you think young children can use Internet } \\
\text { based materials? }\end{array}$} & $\begin{array}{l}\begin{array}{l}\text { Periods } \\
\text { of } \\
10-15 \\
\text { minutes }\end{array} \\
\end{array}$ & \begin{tabular}{|l} 
Periods \\
of \\
$20-25$ \\
minutes \\
\end{tabular} & $\begin{array}{l}\text { Periods of } \\
30-35 \\
\text { minutes }\end{array}$ & $\begin{array}{l}\text { Periods of } \\
40-45 \text { minutes }\end{array}$ \\
\hline
\end{tabular}

Teachers' conceptions about the effects that Internet based materials may exert of the teaching/learning process.

\begin{tabular}{|l|l|l|l|}
\hline Question & YES & MAYBE & N0 \\
\hline 18. Do you believe that ICTs could improve the teaching/learning process in Primary? & & & \\
\hline
\end{tabular}

If your answer to question $\mathrm{n}^{\circ} 18$ was positive, please explain further how ICTs could improve the teaching/learning process, ranking the following items with the following 5 point scale:

1. It does not help;

2. It scarcely helps;

3. It quite helps;

4. It highly helps;

5. It helps very much. 


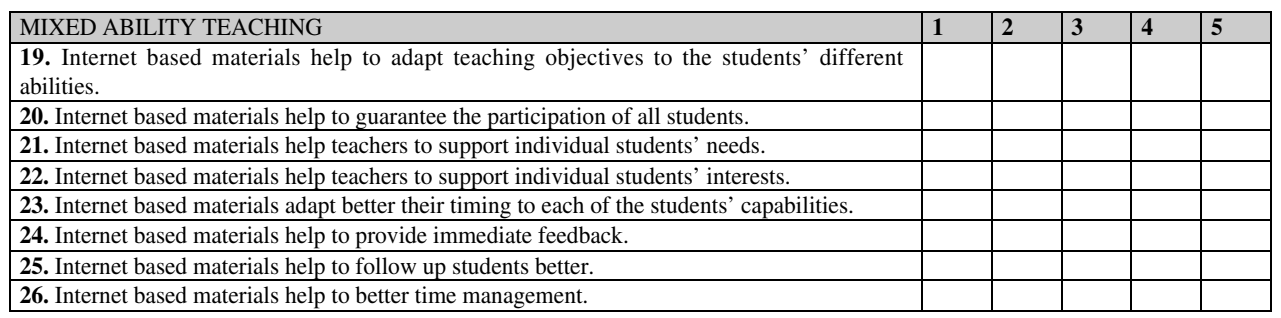

\begin{tabular}{|c|c|c|c|c|c|}
\hline SIGNIFICANT LEARNING & 1 & 2 & 3 & 4 & 5 \\
\hline \multicolumn{6}{|l|}{ 27. Internet based materials help to increase students' motivation. } \\
\hline \multicolumn{6}{|l|}{$\begin{array}{l}\text { 28. Internet based materials help learners to focus their attention on the relevant aspects of } \\
\text { the task. }\end{array}$} \\
\hline \multicolumn{6}{|l|}{ 29. Internet based materials help students to significant learning. } \\
\hline \multicolumn{6}{|l|}{ 30. Internet based materials help learners to connect new content to their prior knowledge. } \\
\hline \multicolumn{6}{|l|}{$\begin{array}{l}\text { 31. Internet based materials help teachers to plan different activities to work on the same } \\
\text { objectives. }\end{array}$} \\
\hline \multicolumn{6}{|l|}{ 32. Internet based materials help students to adopt an active role during the learning process. } \\
\hline \multicolumn{6}{|l|}{ 33. Internet based materials help to learn by playing with amusing methodology. } \\
\hline \multicolumn{6}{|l|}{ 34. Internet based materials help learners to fix and remember better what they have learnt. } \\
\hline \multicolumn{6}{|l|}{$\begin{array}{l}\text { 35. Internet based materials help learners to generalize new contents and apply them to other } \\
\text { context. }\end{array}$} \\
\hline LEARNERS' AUTONOMY & 1 & 2 & 3 & 4 & 5 \\
\hline \multicolumn{6}{|l|}{ 36. Internet based materials help students to choose their own objectives of learning. } \\
\hline \multicolumn{6}{|l|}{ 37. Internet based materials help students to revise their performance in the learning process. } \\
\hline \multicolumn{6}{|l|}{ 38. Internet based materials help students to self assess their own process of learning. } \\
\hline L2 CLASSROOM ENVIRONMENT & 1 & 2 & 3 & 4 & 5 \\
\hline \multicolumn{6}{|l|}{ 39. Internet based materials help to increase the feeling of wellbeing in the classroom. } \\
\hline \multicolumn{6}{|l|}{ 40. Internet based materials help to promote peer collaboration among students. } \\
\hline \multicolumn{6}{|l|}{ 41. Internet based materials help to promote communication in the classroom. } \\
\hline $\begin{array}{l}\text { 42. Internet based materials help students to control their own behaviour in the L2 } \\
\text { classroom. }\end{array}$ & & & & & \\
\hline
\end{tabular}




\section{APPENDIX II}

POST-QUESTIONNAIRE

School ICT facilities and teachers' participation in the research project

\begin{tabular}{|c|c|c|}
\hline \multirow{2}{*}{$\begin{array}{l}\text { Questions } \\
\text { 1. Was it possible for you to have access to the Internet in the foreign language classroom? }\end{array}$} & \multirow[b]{2}{*}{ YES } & \multirow[b]{2}{*}{ NO } \\
\hline & & \\
\hline \multicolumn{3}{|l|}{ 2. If affirmative, how many computers were in the classroom? } \\
\hline 3. If the answer to question $n^{\circ} 1$ is negative, how often could students use the computer lab? & & \\
\hline 4. How long did students work with Internet based materials per week? & & \\
\hline
\end{tabular}

Teachers' experience with Internet based materials during the research project

\begin{tabular}{|c|c|c|c|c|c|}
\hline \multirow[b]{2}{*}{ Questions } & \multicolumn{5}{|c|}{ Frequency } \\
\hline & $\begin{array}{l}\text { Neve } \\
r\end{array}$ & $\begin{array}{l}\text { Between } \\
1 \text { and } 6 \\
\text { times a } \\
\text { year }\end{array}$ & $\begin{array}{l}\text { Between } \\
7 \text { and } 12 \\
\text { times a } \\
\text { year }\end{array}$ & $\begin{array}{l}\text { Between } \\
2 \text { and } 4 \\
\text { times a } \\
\text { month }\end{array}$ & $\begin{array}{l}\text { More } \\
\text { than } \\
\text { once a } \\
\text { week }\end{array}$ \\
\hline \multicolumn{6}{|l|}{ 5. ¿How often did you use Internet based materials? } \\
\hline \multicolumn{6}{|l|}{$\begin{array}{l}\text { 6. ¿Did you search for digital resources and Internet web sites to } \\
\text { complement your teaching? If so, how often? }\end{array}$} \\
\hline $\begin{array}{l}\text { 7. Please, rank the usefulness and value of the following Internet-based } \\
\text { materials: }\end{array}$ & Null & $\begin{array}{l}\text { Minimu } \\
\mathrm{m}\end{array}$ & Medium & $\begin{array}{l}\text { High } \\
\text { value }\end{array}$ & $\begin{array}{l}\text { Very } \\
\text { high } \\
\text { value }\end{array}$ \\
\hline \multicolumn{6}{|l|}{ 7.1. Tales } \\
\hline \multicolumn{6}{|l|}{ 7.2. Songs } \\
\hline \multicolumn{6}{|l|}{ 7.3. Games } \\
\hline \multicolumn{6}{|l|}{ 7.4. Others (detail them): } \\
\hline \multicolumn{4}{|c|}{$\begin{array}{l}\text { 8. Did you have any problem when using any of the above mentioned Internet based activities in the } \\
\text { classroom? }\end{array}$} & YES & NO \\
\hline \multicolumn{6}{|l|}{ 9. Do you have any suggestion to optimize its use? } \\
\hline \multirow{2}{*}{\multicolumn{4}{|c|}{$\begin{array}{l}\text { 10. Now that you have used them, would you recommend these Internet based materials to be used by } \\
\text { children at home? }\end{array}$}} & YES & NO \\
\hline & & & & & \\
\hline \multicolumn{6}{|l|}{ 11. Why? } \\
\hline
\end{tabular}

Teachers' beliefs and opinions about the usefulness of Internet based materials as a tool to teach foreign languages after the research project. Please, answer the following questions using a 5 point scale:

1. It does not facilitate learning;

2. It scarcely helps learning;

3. It quite helps learning;

4. It highly facilitates learning;

5. It helps learning very much. 


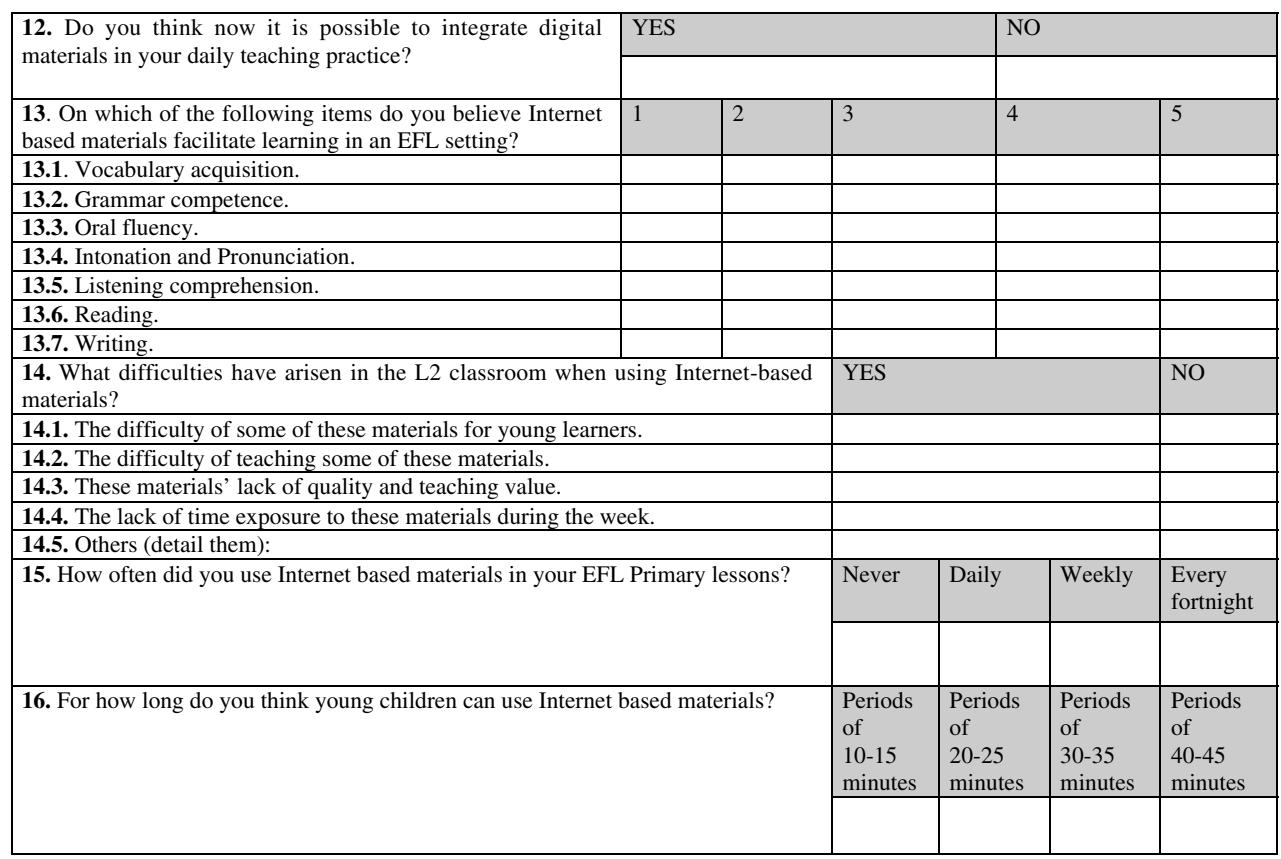

Teachers' conceptions about the effects that Internet based materials may exert of the teaching/learning process after the research project.

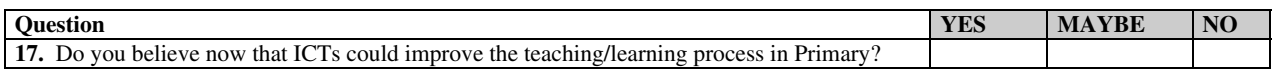

If your answer to question $n^{\circ} 17$ was positive, please explain further how ICTs could improve the teaching/learning process, ranking the following items with the following 5 point scale:

1. It does not help;

2. It scarcely helps;

3. It quite helps;

4. It highly helps;

5. It helps very much.

\begin{tabular}{|c|c|c|c|c|c|}
\hline MIXED ABILITY TEACHING & 1 & 2 & 3 & 4 & 5 \\
\hline $\begin{array}{l}\text { 18. Internet based materials help to adapt teaching objectives to the students' different } \\
\text { abilities. }\end{array}$ & & & & & \\
\hline 19. Internet based materials help to guarantee the participation of all students. & & & & & \\
\hline $\begin{array}{l}\text { 20. Internet based materials help to adequate the teachers' help to the needs of each one of } \\
\text { the students. }\end{array}$ & & & & & \\
\hline 21. Internet based materials can adequate better to each one of the students' interests. & & & & & \\
\hline 22. Internet based materials adapt better their timing to each of the students' capabilities. & & & & & \\
\hline 23. Internet based materials help to provide immediate feedback. & & & & & \\
\hline 24. Internet based materials help to follow up students better. & & & & & \\
\hline 25. Internet based materials help to better time management. & & & & & \\
\hline
\end{tabular}




\begin{tabular}{|c|c|c|c|c|c|}
\hline \multirow{2}{*}{\multicolumn{6}{|c|}{$\begin{array}{l}\text { SIGNIFICANT LEARNING } \\
\text { 26. Internet based materials help to increase students' motivation. }\end{array}$}} \\
\hline & & & & & \\
\hline \multicolumn{6}{|l|}{$\begin{array}{l}\text { 27. Internet based materials help learners to focus their attention on the relevant aspects of } \\
\text { the task. }\end{array}$} \\
\hline \multicolumn{6}{|l|}{ 28. Internet based materials help students to significant learning. } \\
\hline \multicolumn{6}{|l|}{ 29. Internet based materials help learners to connect new contents to their prior knowledge. } \\
\hline \multicolumn{6}{|l|}{$\begin{array}{l}\text { 30. Internet based materials help teachers to plan different activities to work on the same } \\
\text { objectives. }\end{array}$} \\
\hline \multicolumn{6}{|l|}{ 31. Internet based materials help students to adopt an active role during the learning process. } \\
\hline \multicolumn{6}{|l|}{ 32. Internet based materials help to learn by playing with amusing methodology. } \\
\hline \multicolumn{6}{|l|}{ 33. Internet based materials help learners to fix and remember better what they have learnt. } \\
\hline \multicolumn{6}{|l|}{$\begin{array}{l}\text { 34. Internet based materials help learners to generalise new contents and apply them to other } \\
\text { context. }\end{array}$} \\
\hline LEARNERS' AUTONOMY & 1 & 2 & 3 & 4 & 5 \\
\hline \multicolumn{6}{|l|}{ 35. Internet based materials help students to choose their own objectives of learning. } \\
\hline \multicolumn{6}{|l|}{ 36. Internet based materials help students to revise their performance in the learning process. } \\
\hline \multicolumn{6}{|l|}{ 37. Internet based materials help students to self assess their own process of learning. } \\
\hline L2 CLASSROOM ENVIRONMENT & 1 & 2 & 3 & 4 & 5 \\
\hline \multicolumn{6}{|l|}{ 38. Internet based materials help to increase the feeling of wellbeing in the classroom. } \\
\hline \multicolumn{6}{|l|}{ 39. Internet based materials help to promote peer collaboration among students. } \\
\hline \multicolumn{6}{|l|}{ 40. Internet based materials help to promote communication in the classroom. } \\
\hline $\begin{array}{l}\text { 41. Internet based materials help students to control their own behaviour in the L2 } \\
\text { classroom. }\end{array}$ & & & & & \\
\hline
\end{tabular}

Please rank your participation in the research project using a 5 point scale:

\author{
1. False - 5. True
}

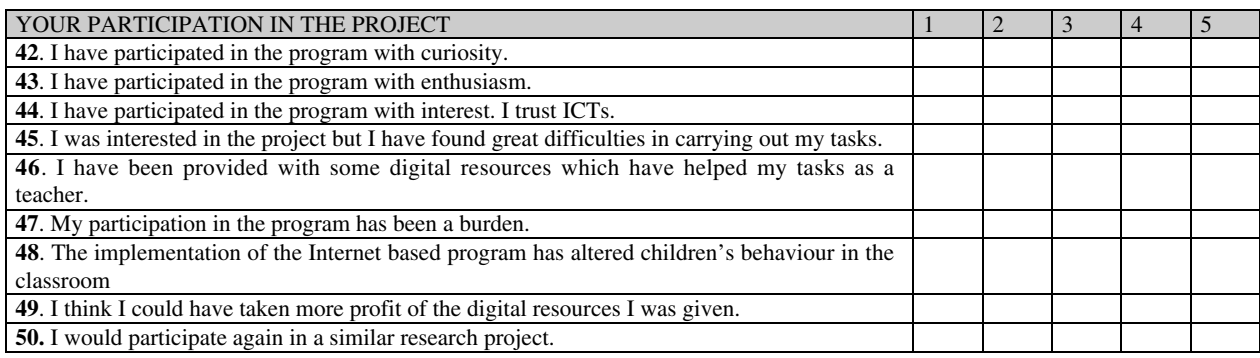

List the 3 most positive aspects of the digital activities you have used in the classroom.

List the 3 most negative aspects of the digital activities you have used in the classroom.

Please make some suggestions to improve the implementation of the digital program in Primary.

Please make a general assessment of the research project. 